\title{
Studying the motivation requirement of the university students on the looking and training of education on rest platforms in the internet-environment
}

\section{G. Rzhevsky}

Department of Social Pedagogy and Information Technologies in the Education, National University Life and Environmental of Ukraine.

Corresponding author. E-mail: manpower44444@gmail.com

Paper received 15.01.18; Accepted for publication 20.01.18.

https://doi.org/10.31174/SEND-PP2018-153VI63-11

Abstract. The article defines the conceptual foundations of the fundamentalization of professional training of future specialists in the field of information technologies on the basis of the laws of dialectics and philosophical categories. It is proved that natural-scientific, mathematical and philosophical laws and concepts are fundamental for computer disciplines in the hardware and software parts of computer. The principle of two-level continuous fundamentalization of professional training of future IT specialists is developed.

Keywords: laws of dialectics, philosophical categories, fundamentalization, informational technologies, professional activity, professional training, IT-specialist.

The relevance of the study of psycho-pedagogical specificity of learning in the Internet environment is undoubtedly important in modern conditions and has its own peculiarities.

Today interactive distance learning methods are gaining the wide popularity in the world, they are based on purposeful and controlled intensive independent work of a student who can study in a comfortable place, on personal schedule (without a visit to the University) and under the guidance of experienced teachers-tutors.

Distance educational form is recognized equal to full-time and postal tuition by the Ministry of education and science of Ukraine.

Attention to the individuality of a student and to his necessity for the study content is one of the modern requirements to the educational system. Studying in the Internet environment on distance education allows students in the new social and economic complicated and uncertain conditions to be broadly educated person who has flexibility to change the content of its activities in connection with the changing requirements of the modern labor market.

Formulation of the problem. Students who work in the system of distant education, develop their professional selfimprovement under the condition they have an access to the resources hosted in the Internet environment of the institution. Exactly a student determines his own level of professional preparation. In addition, the computer allows to selfcontrol in different forms all the time, which increases the level of motivation and level of creativity of student's studies. So, the Internet environment can be seen as a space of selfactualization of the personality.

The use of modern computer and Internet technologies in the University students distance education allows to improve their cognitive processes. Multidirectional effect of information, music, colorful images also has a strong emotional impact on students.

However, in the development and implementation of new technique should take into account the physiological and psychological characteristics of students. Thus, the senses of the students are able to capture only limited amount of information from the Internet and the surrounding environment. There is also the "psychological effect of oversaturation", which means that a student is not capable to face a monotonous task without the variation even for a short time. Distance study is one of the new realities of modern education in present conditions. In regard with the acceptance of the new education standards in Ukraine there is a need for improvement of the distance educational Internet environment which will provide the opportunity to learn and to get the qualification promotion courses available on the remote platform.
Distance education is fundamentally different with its influence from the traditional forms of studies. When considering distance education as a modern teaching Internet technology and activity mediated by information and computer technologies, it should be noted that it is characterized by a number of psycho-pedagogical features in comparison with traditional forms of learning.

Studies in the Internet environment on the distance education essentially change the role positions of a teacher and a student. In the traditional form of learning a teacher acts as an interpreter of knowledge. With the extension of the educational space, a student receives the function of the knowledge interpretation and the teacher acts as a coordinator of this acquired knowledge. He advises students and guides the work of the cognitive processes of a student, that is, takes the responsibility for supporting the professional development of the student.

Basically the distance education is a priority in all the countries.

Experts in this field predict the dominance of distance education over traditional forms of education and their complete displacement in the future. But probably this will not happen.

The popularity of distance education grows, because it has a lot of advantages.

For the first, it is mass. The number of people studying on the same study programme in the same University, is determined only by the characteristics of the communication equipment. By the way, specifically the popularity and accessibility was the motivation for the emergence of the distance education.

The second advantage of the distance education is the "speed".

The third advantage of the distance education is comparative low cost of the knowledge obtaining. However, unfortunately, there are few educational institutions which offer the distance education in its pure form and to receive a diploma of all the specialties in Ukraine.

Methods. To solve the research tasks, a complex of complementary research methods was used: theoretical - analysis of the problem of motivation of students and teachers in modern scientific literature; generalization of scientific sources from the mentioned problem; empirical - observation (used to study the features of service and training activities); to study multivector influence of Internet networks, we conducted a sociological survey of students and teachers, the method of conducting a survey was chosen - questionnaires were distributed by the distribution method; empirical questioning, testing; method of statistical processing of results: quantitative and qualitative analysis of the results ob- 
tained during the diagnosis; mathematical calculations of primary descriptive statistics. For statistical processing, computer programs Microsoft Excel 2010 were used.

The purpose of our study was to detect the need of students of the Kyiv national University of Trade and Economics of different forms of learning to study on the distance form and to identify what exactly they need this distance form of education for. On the basis of this, the researchers set themselves the following tasks: to determine what students need the distance form of education for; to define separate disciplines which students want to study distantly.

The object of the researches were students of all courses, because we were interested to analyze the responses of the majority, rather than a specific course or group.

For the solution of the set tasks this sociological research presupposed the use of quantitative method of gathering of the information - the questionnaire.

In total, 1260 respondents were interviewed (students of different courses and faculties).

I shared the university students who participated in our study: the first course -262 students are equal to $20.8 \%$; the second course -332 students is $26.4 \%$; the third course 257 students make 20.4 per cent; the fourth course - 347 students, is 27.6 per cent; the fifth course - 62 students is equal to is $4.8 \%$.

Students, who took part in the research, were of the fulltime form of education (674 students, that is $53.5 \%$ of respondents), and of the part-time education form (586 students, which is equal to $46.5 \%$.).

The dividing of students by field of study: Management 226 students (12.0\%); Psychology - 113 students (2.0\%); Tourism - 162 students (7.2\%); Law - 15 students (3.1\%); Marketing - 17 students (3.2\%); Enterprise economy - 21 students (6.3\%); international Economics - 26 students (3.2\%); Finance and credit - 202 students (17.8\%); Economic Cybernetics - 89 students (3.4\%); Accounting and auditing - 9 students (11.3\%); Advertising and public relations - 110 students $(2.7 \%)$; Food technology and engineering - 12 students $(3.8 \%)$; Hotel and restaurant industry - 41 students $(5.4 \%)$; Commodity research and trade entrepreneurship 217 students $(17.9 \%)$.

Dividing of answers concerning access to the INTERNET is the following, the answer "Yes" said 943 students (74.9\% of the total amount); the answer "No" said 317 students $(25.1 \%)$.

On the picture 5. Dividing of answers regarding having courses on compact-disks were partitioned in the following manner, the answer "Yes" said 564 students or $44.8 \%$ of the total sample; the answer "No" said the 338 students or $26.9 \%$ of the total sample; the answer "Difficult to answer" mentioned 358 students or $28.3 \%$ of the total sample.

The dividing of responses on the desire to have round the clock access to electronic library The system of distance education were as follows, the answer "Yes" mentioned 677 students or $53.6 \%$ of the total sample; the answer "Rather Yes" said 428 of student or $34.0 \%$ of the total sample; the answer "Rather no" indicated 85 students or $6.8 \%$ of the total sample; the answer "No" mentioned 70 students or $5.6 \%$ of the total sample

The students gave answers to the question whether they need the distant education "To explore the basic disciplines of the curriculum" in the following manner: 449 students or $35.7 \%$ of the total sample mentioned, the answer "Yes"; 335 students or $26.7 \%$ of the total sample indicated the answer
"Rather Yes"; 186 students or $14.8 \%$ of the total sample gave the answer "Rather no"; the answer "No" was noted by 186 students or $14.8 \%$ of the total sample; 100 students or $8.0 \%$ of the total sample mentioned the response "Difficult to answer".

The students gave answers to the question whether they need the distance education "For the study of individual disciplines" in the following manner, namely: the answer is "Yes" was given by the 549 students or $43.6 \%$ of the total sample; 393 students or $31.2 \%$ of the total sample gave the answer "Rather Yes"; the answer "Rather no" was mentioned by 183 students or $14.5 \%$ of the total sample; 108 students or $8.6 \%$ of the total sample noted the answer "No"; the response "Difficult to answer" was given by 28 students or $7.1 \%$ of the total sample.

The students gave answers to the question whether they need the distance education "to studyadditional disciplines" in the following manner, namely: the answer is "Yes" was mentioned by 456 students or $36.2 \%$ of the total sample; the answer "Rather Yes" was given by 366 students or $29.1 \%$ of the total sample; 187 students or $14.9 \%$ of the total sample noted the answer "Rather no"; 123 students or $9.8 \%$ of the total sample gave the answer "No"; the response "Difficult to answer" was indicated by 128 students or $10.0 \%$ of the total sample.

The students answered the question whether they need the distance education "to prepare to the control of knowledge" in the following manner, namely: the answer "Yes" was given by 583 students or $46.0 \%$ of the total sample; the answer "Rather Yes" was indicated by 293 students or $23.3 \%$ of the total sample; 173 students or $13.8 \%$ of the total sample mentioned the answer "Rather no"; the answer "No" was given by 125 students or $10.0 \%$ of the total sample; 86 students or $6.9 \%$ of the total sample indicated the response "Difficult to answer".

The students answered the question whether they need the distance education "to pass the academic difference" in the following manner, namely: the answer is "Yes" was given by 326 students or $25.9 \%$ of the total sample; the answer "Rather Yes" was mentioned by 259 students or $20.6 \%$ of the total sample; 224 students or $17.8 \%$ of the total sample gave the answer "Rather no"; the answer "No" was indicated by 286 students or $22.7 \%$ of the total sample; the response "Difficult to answer" was given by 165 students or $13 \%$ of the total sample.

In further analysis, all the rates of the results of the study will be presented as a percentage of all respondents who gave an answer. Further we quote the results of the analysis of students ' answers to the set of questions in which students need to specify the disciplines for the distance education and to mention what they need it for.

As shown by the results of the study, the discipline "Audit" was chosen to study by $46.1 \%$ of respondents. Also we may note a large value of $42.1 \%$, which indicates that the same discipline would chosen for preparation for the knowledge control.

As you can see the subject "accounting" was chosen to study in addition by almost the half of the respondents. It is $44.9 \%$ of the total number of respondents. $37.2 \%$ of respondents did not choose this discipline. $44.3 \%$ would like to study accounting for the preparation for knowledge control.

The discipline "Money and credit" was chosen for the study, as in the previous table, by $46 \%$ of respondents. $31.7 \%$ of the respondents didn't choose this discipline. $22.3 \%$ 
said they find it difficult to answer. $42.3 \%$. chose this discipline for preparation.

With regard to this discipline, we can see that the percentage of those who chose this discipline is a little bit less than with the previous discipline. It makes up $33.7 \%$ of all the respondents. Also there is a smaller percentage of those who would choose the discipline of Public procurement for preparation for knowledge control. It is $34.1 \%, 35.7 \%$ would not select it and $28.3 \%, 30.2 \%$ responded that it was difficult to answer.

We see that $38.6 \%$ of respondents chose this subject to study additionaly, $34.2 \%$ would not choose at all, $27.2 \%$ gave the reply "it was is difficult to answer". $36.7 \%$ would chose a subject to prepare for the control, $34.3 \%$ would not choose it and $29 \%$ gave the answer "it was difficult to reply".

Here the answers were divided as follows: $43.6 \%$ of respondents noted that they chose this discipline for the additional study, $33.2 \%$ would not like to study it optionally. $23.2 \%$ could not decide. To prepare for the control of knowledge this subject was chosen by $38.9 \%$ of respondents, $36.5 \%$ did not choose it.

We see the following: the question whether they chose this discipline for additional study, 27.6\% replied "Yes", $46.6 \%$ said "No". 25.8\% wrote "Difficult to answer". To prepare the subject for control, 32.5\% replied "Yes,", 39.5\% mentioned "No", and $28 \%$ chose the option "Difficult to answer".

Almost half of the respondents, 47.3\%, answered "Yes" regarding the study of this discipline additionally, $30.8 \%$ answered "No". $21.9 \%$ doubted and answered "Difficult to answer". Concerning whether students would choose the discipline to prepare for control, the dividing is the following. 43.2\% replied "Yes", 29.6\% answered "No",'Difficult to answer" was noted by $27.2 \%$.

On the discipline 39.7\% answered "Yes", 26.3\% said "No", and $34 \%$ gave the reply "Difficult to answer". To prepare for control, $42.3 \%$ replied "Yes , 31.7\%, said "No" and the option "Difficult to answer" was chosen by $26 \%$.of respondents.

Here we see the following picture: For additional studying, 51.2\% replied "Yes", 28.1\% said "No", 20.7\%. had troubles and answered "Difficult to reply". 40.8\% chose specifically this discipline for control," $33.9 \%$ answered No" and "cannot say" was chosen by $25.3 \%$.

To study additional $32.4 \%$ chose "Yes", "No" was indicated by $42.6 \%, 25 \%$ chose the option "Difficult to answer". To prepare for the control 33.6\% replied "Yes", 39.5\% mentioned «No", "Hard to say"was noted by $26.9 \%$.

As shown by the results of the study, this discipline would be interested to study additionaly by $36.9 \%, 40.5 \%$ answered "No", $22.6 \%$ gave the reply "Difficult to answer". To prepare for the control of knowledge 37.7\% replied "Yes", 35.8\% answered "No", "Hard to say" was said by $26.5 \%$.

On this discipline the results of the study show the following: for additionl studying, $43.1 \%$ replied "Yes", "No," was said by $34.9 \%, 22 \%$ chose the option "Difficult to answer". To prepare for the control of knowledge 38.5\% answered "Yes", 37.3\%. noted the answer "No".

The answers were divided as follows: for additionl studying, 36.7\% of respondents replied "Yes", "No" was indicated by $40.2 \%$, "Hard to say" was noted by $23.1 \%$. To prepare for control, "Yes" was chosen by 36.6\%, 37.5\% said "No", $25.9 \%$ noted "Hard to say".

To study additionally $41.4 \%$ noted "Yes", "No" was indi- cated by $36 \%, 22.6 \%$ had troubles with reply. To prepare for the control 37.5\% responded "Yes", 36.1\% mentioned "No", $26.4 \%$ gave the answer "Difficult to answer".

For additional studying, "Yes" answered 40.5\%, "No" was indicated by $37.8 \%, 21.7 \%$ gave the answer "Difficult to reply". To prepare for the control "Yes" was answered by $39.3 \%, 34.6 \%$ replied "No" and "Hard to say" was mentioned by $26.1 \%$.

Marketing comparing to other disciplines was selceted by a larger number of respondents. We can see that to study the discipline 54.3\% answered "Yes" and for the preparation for the control $64.8 \%$ also said "Yes".

As we can see this discipline was chosen for additional study by $54.5 \%$ oa respondents, the variant "No" was chosen by $29.5 \%, 16 \%$ indicated the answer "Difficult to answer". To prepare for the control 38.1\% answered "Yes", 34.4\% said "No" and 27.5\% mentioned "Difficult to answer".

Here the answers were as follows: $28.3 \%$ of respondents would like to study additionally, for the preparation for the control $34.4 \%$ of the respondents replied "Yes".

$72.2 \%$ of Respondents wish to study the discipline additionally, $15.2 \%$ said "No," for the preparation for the control it was selected by $45.2 \%$ of respondents, it is also a considerable percentage of $36.6 \%$ answered "No".

As shown by the dividing "Yes" was answered by 59\%, "No" was mentioned by $29.5 \%$, and $11.5 \%$ chose the option "Difficult to answer". $45.3 \%$ would like to study the discipline for the preparation for knowledge control. 32.6\% noted "No" and 22.1\% said "Difficult to say".

$39.7 \%$ noted "Yes" to study additionally. "No" was indicated by $41.9 \%$ of respondents, $18.4 \%$, could not reply to the question, noting "difficult to say" As for the choice of this discipline for preparation for the control of knowledge, the answers are a little bit different. 40.4\% answered "Yes", "No" was noted by $43.9 \%$ and "Difficult to answer" was mentioned by $15.7 \%$.

The dividing showed the following: $46.8 \%$ want to study the subject additionally, the variant "No" was chosen by $38.3 \%$, "difficult to say" was chosen by $14.9 \% .47 .3 \%$ would like to prepare the subject for control, $41.3 \%$ answered "No" and $11.4 \%$ gave the answer "Difficult to answer".

$37.5 \%$ wish to study the discipline additionally, $48.8 \%$ answered "No", $13.7 \%$ mentioned the variant "Difficult to answer". $35.5 \%$ chose this discipline for preparation for the control of knowledge, $40.1 \%$ replied "No and $24.4 \%$ indicated "Difficult to say" as their reply.

As we can see, this discipline is interesting to be additionally studied by $29.8 \%$, "No" was chosen by the biggest part, by $55.1 \%, 15.1 \%$. said "Difficult to say" To reply whether they would choose the discipline to prepare for the knowledge control the variant "Yes" was chosen by $41.3 \%$, $47.9 \%$, replied "No" $10.8 \%$ chose the variant "Difficult to say".

The dividing showed the following: $45.1 \%$ chose the discipline for additional study, $34.5 \%$ replied "No" and "Difficult to say" was indicated by $20.4 \%$ of respondents. To prepare for the control the answer "Yes" was mentioned by $37.9 \%, 47.6 \%$ said "No" and $14.5 \%$ were unsure with their reply.

As shown by the dividing, only $12 \%$ would like to study this discipline additionally, $82.1 \%$ responded "No" and $5.9 \%$ chose the variant "Difficult to answer". We can see the other situation with the questions whether you would like to chose this discipline for the control of knowledge. $33.2 \%$ replied 
"Yes", 54.2\% do not want to select the discipline, "Difficult to say" was said by $12.6 \%$.

As we can see, according to the table, for additional study $44.8 \%$ of the respondents noted "Yes", $35.3 \%$ gave the answer "No" and $19.9 \%$ replied "Difficult to answer". To prepare for control, 45.4\% replied "Yes", 40.8\% answered "No" and 13.3 gave the answer "Difficult to answer".

This table can show us the following conclusions: $34.5 \%$ wish to study this discipline additionally, the answer "No" was given by $56.6 \%$. $8.9 \%$ of respondents had difficulties with the reply. To prepare for control "Yes" was given by $40.1 \%$ of respondents, $39.8 \%$ chose the variant "No", " Difficult to answer" was mentioned by $20.1 \%$.

As shown by the dividing, $59.6 \%$ would like to study this discipline additionally. "No" was noted by $28.5 \%$, "Difficult to answer" was chosen by $11.9 \%$. For the preparation of control "Yes" was noted by 45.9\%, 32.8\% replied "No" and $21.3 \%$ mentioned they cannot answer the question.

According to the dividing, we can see the following: $24.5 \%$ would like to study the discipline additionally, "No" was noted by $69.7 \%, 5.8 \%$ of respondents said "Difficult to answer". With regard to choosing the discipline for preparation for the control, the situation is different. $42.2 \%$ replied "Yes", "No" was chosen by $49.6 \%$ and $8.2 \%$ was unsure and replied "Difficult to say".

The results of the study showed the following: $56.7 \%$ would like to study the discipline additionally, the option "No" was chosen by $28.4 \%, 14.9 \%$ selected the variant "Difficult to answer". To prepare for control, "Yes" was answered by $47.8 \%, 42.2 \%$ replied "No" and only $10 \%$ said "Difficult to say".

As we can see, according to the table, have the following dividing:. 29.7\% wanted to study the discipline additionally, "No" was answered by $64.1 \%, 6.2 \%$ indicated the option "Difficult to answer". To prepare for the control 37.6\% answered "Yes",46.5\% mentioned "No" and the option "Difficult to answer" was chosen by $15.9 \%$.

To additionally study the discipline and the answer "Yes" was chosen by $53.4 \%$, 39.7\% selected the option "No", "Difficult to say" was chosen by $6.9 \%$. To prepare for the control, "Yes" was mentioned by $38.6 \%$, 40.2\% replied "No" and $21.2 \%$ chose the option "Difficult to answer".

The dividing of responses showed the following: $29.3 \%$ would like to study the discipline additionally, "No" was noted by $62.8 \%$, "Difficult to say" was chosen by $7.9 \%$. To prepare for the control, $41.8 \%$ answered "Yes", "No" was selected by $52.5 \%$, the option "Difficult to answer" was chosen by $5.7 \%$.

"Yes" for studying the discipline was chosen $46.8 \%$, $43.8 \%$ replied "No", 9.4\% indicated "Difficult to answer". To prepare for control, "Yes" was noted by $61.3 \%, 27.4 \%$, chose the reply "No", "Difficult to answer" was mentioned by $11.3 \%$.

The dividing of responses showed the following: Additional study and the option "Yes" was chosen by $48.4 \%$, $30.1 \%$ answered "No", $21.5 \%$ chose the option "Difficult to answer". To prepare for the control, Option "Yes" was chosen by $53.1 \%$, 34.2\% replied "No" and "Hard to say" was mentioned by $12.7 \%$.

As we can see, according to the research, $44.4 \%$ of respondents would like to study the discipline additionally, $36.9 \%$ said they wished to study it to prepare for the control.

According to the results of the research on this discipline, the responses were the following: an option for additional study was chosen by $49.3 \%, 21.9 \%$ selected the option "No", $18.8 \%$ said "Difficult to say". Then, to prepare for control $54 \%$ answered "Yes", "No" was noted by $36.4 \%$, 9.6\% had difficulties with reply.

The dividing of answers showed us that this discipline is among of the first places for additional study. $73.8 \%$ of respondents answered "Yes," 19.4\% responded "No", 6.9\% had some difficulties with the response and noted "Difficult to answer". As for the training for control the answers were divided like following: "Yes" was given by $55.7 \%$, "No" was selected by $34.5 \%$ and $9.8 \%$ said "Difficult to answer".

This discipline additionally would like to be studied by $54.4 \%$, the option "No" was chosen by $30.7 \%$. The large percentage wants to study this discipline to prepare for control. This amounts $86.9 \%$.

$57 \%$ would chose the discipline for the additional study, $37.5 \%$, said "No" and the answer "Difficult to say" was given by $10.5 \%$. To prepare for control, $18.1 \%$ replied "Yes" ,"No" was said by $79.4 \%$, "Difficult to say" was noted by $2.5 \%$.

The research results for this discipline show the following: for additional study this discipline would be selected by $28.4 \%$, "No" was mentioned by $63.7 \%$, the option "Difficult to answer" was chosen by $7.9 \%$. To prepare for the control $58.9 \%$ answered "Yes", 35.4\% replied "No".

The fundamentals of law additionally would like to be studied by $72.1 \%, 18.4 \%$ noted "No" and $9.5 \%$ remained uncertain. To prepare for the control, 42.2\% said "Yes", "No" was given by $39.6 \%$, "Difficult to say" was mentioned by $18.2 \%$.

The dividing of answers on this discipline shows the following.: to study it additionally $29.3 \%$ said "Yes". The option "No" was chosen by $43.9 \%, 26.7 \%$ were unsure with the answer. To prepare for the knowledge control $49.9 \%$ would chose the variant "Yes", the option "No" was chosen by 41.4\%. 8.7\% mentioned they had difficulties with answer.

As we can see the results of the research, $72.1 \%$ would like to study the discipline additionally. There is the great quantity of respondents who would choose the discipline for the preparation for the control $-62.5 \%$.

According to this table, we can see the following: $84.3 \%$ of respondents want to study the discipline additionally, $11.9 \%$ chose the option "No", 3.8\% mentioned "Difficult to answer". To prepare for the knowledge control, "Yes" was chosen by $48.2 \%$, "No " was given by $42.8 \%, 9 \%$ is uncertain with the reply.

The majority of respondents would choose this discipline to prepare for the knowledge control. It is $63.7 \%, 28.9 \%$ said "No" and only $7.4 \%$ gave the answer "Difficult to answer". A much smaller percentage of respondents would study it additionally. "Yes" was responded by $36.8 \%, 38.9 \%$ gave the answer "No" and the Option "Difficult to answer" was chosen by $24.2 \%$.

We obtained the following results on the discipline: for additional study, "Yes" was replied by 44.1\%, 47.8\% said "No" and $8.1 \%$, gave the answer "Difficult to answer". To prepare for the control of knowledge 12.4\% replied "Yes", $7.1 \%$ gave the answer "No" and $80.5 \%$ indicated "Difficult to answer".

On self-study of this discipline, the respondents gave the following answers: we received "Yes" from 77.4\%, we got "No" from $18.4 \%$, "Dificult to say" was noted by $4.2 \%$. To prepare for the knowledge control 39.8\% responded "Yes", "No" was given by $32.8 \%$ and $27.4 \%$ chose the option "Dif- 
ficult to answer".

"Personnel management" also was chosen by many of the respondents for additional study. Among the suggested options $64.2 \%$ answered "Yes", $27.9 \%$ replied "No" and 7.9\% chose the option "Difficult to answer". Concerning the preparation for the control, the results are as follows: $45.95 \%$ answered "Yes", 30.7\% gave reply "No", " Difficult to answer" was chosen by $23.4 \%$.

As we can see from the results on this discipline, $31.6 \%$, want to study it additionally, the option "No" was chosen by $40.4 \%$, the option "Difficult to answer" was selected by $28 \%$ of respondents. To prepare for control, "Yes" was said by $34.9 \%$, "No" was chosen by $54.9 \%$ and $10.2 \%$ of respondents noted the option "Difficult to say".

The research showed that $39.5 \%$ would like to study this discipline additionally, $34.5 \%$ answered "No" and $26.3 \%$ chose the option "Difficult to say". The same discipline, but for preparation for the knowledge control was selected by $28.8 \%$ of respondents. $13.3 \%$ of the respondents answered "No", $57.9 \%$ gave the answer "Difficult to answer".

Conclusions. Thus, based on the prior results of the research we came to the conclusion about the necessity of organization of psychological and pedagogical support in the process of distance study implementation. This need is caused by the fact that all subjects of distance study: students, teachers, developers of teaching and learning materials, parents, beginners in training (interaction) in the Internet, are often faced with difficulties of a psychological nature.

The basis of the distance study of the University is distance courses of each subject, provided with study programmes at the University.

We have defined motivational needs regarding the passage and the desire to use the distance study system while studying.

The specificity of the courses is an important component in determining the necessary of the instruction or preparation course for the semester control.

In its turn, distance courses consist of teaching materials, programs and work programs of educational disciplines, textbooks, presentations, practical tasks with the methods of their implementation, tests for self-control, other tests and exams.

Distance study courses were created by scientific and pedagogical staff of the University. They are provided to the student from e-librariy of the distance study system via the

\section{INTERNET}

Distance study work on the subject is organized by the teacher who provides the student with comprehensive advice on the study of the theoretical part of the material, practical assignments and passing of remote testing. The minimal time of independent work of the student is seven hours a week.

Communication between a student and a teacher is held through email.

Through the system of distance study students navigate in the educational material, the students can: read the programs of training, methodical materials for independent work, lectures and other training materials; write and send questions to the teachers through email; copy practical tasks and methodological materials for their fulfillment to their computers; test their knowledge with the help of self - tests on each training module; to participate or initiate discussion of different questions on forums to communicate with students and teachers online.

After the successful completion of study students receive a certificate of the established sample.

Thus, based on the prior results of the research we came to the conclusion about the necessity of organization of psychological and pedagogical support in the process of distance study implementation. This need is caused by the fact that all subjects of distance study: students, teachers, developers of teaching and learning materials, parents, beginners in training (interaction) in the Internet, are often faced with difficulties of a psychological nature.

We have defined motivational needs regarding the passage and the desire to use the distance study system while studying.

According to the results of students ' answers, we observe that the majority of them wish to study on distance educational form. In the basis of the distance education of the University we can find online courses on each subject, provided by programmes of study at the University.

Also, we chose specific courses of disciplines to obtain new knowledge which is not provided byeducational programmes, courses which allowed to improve the knowledge ondisciplines of the specialty. Also, most students noted that distance ducation will be useful to them during preparation for the module and semester control.

The specificity of the courses is an important component in determining the necessary of the instruction or preparation course for the semester control.
1. Abramov S.M. (2003) Vospytanye obrazovatelnoi samostoiatelnosty studentov humanitarian vuzov v protsesse dystantsyonnoho obuchenyia [Education of the educational independence of students of humanitarian universities in the process of distance learning ] Avtoref. dys. na soysk. uchen. step, k.p.n. Ekaterynburh -22 .

2. Bespalko V.P., Tatur Yu.H. (1989) Systemno-metodycheskoe obespechenye uchebno-vospytatelnoho protsessa podhotovky spetsyalystov [System-methodical support of the educational process of the training of specialists] Ucheb,-metod.posobye. Moscow, Russia - 144 .

3. Morev Y. A. (2004) Obrazovatelnыe ynformatsyonnыe tekhnolohyy. Chast 3. Dystantsyonnoe obuchenye. - Vladyvostok: Yzdvo Dalnevostochnoho unyversyteta,. - 150.

4. Rzhevskyi, H., Korolchuk V., Korolchuk, M. (2014) Praktychna psykholohiia : navch. posib. dlia stud vyshch. navch. zakl. - K. : Kyiv. nats. torh.-ekon. un-t,. -728.

5. Rzhevskyi, H.M. (2017) Doslidzhennia rivnia korystuvannia

\section{ENCES}

studentamy internet-seredovyshchem pid chas navchannia [Study of the level of use of the student by the Internet environment during the training] Aktualni naukovi psykholohichni ta pedahohichni doslidzhennia suchasnosti : VI-ta Vseukrainska naukova Internet-konferentsiia (26-27 zhovtnia 2017 r.): tezy ta statti dop. // Vidp. Red. H. Rzhevskyi, T. Perepeliuk. - K. : NUBiP - 24-36.

6. Rzhevskyi, H.M. (2017) Dystantsiina forma navchannia v suchasnykh umovakh : psykholoho-pedahohichni osoblyvosti [Distant form of psychology and pedagogy of the person] Naukovyi visnyk Natsionalnoho universytetu bioresursiv i pryrodokorystuvannia Ukrainy. Seriia «Pedahohichni nauky» / Redkol.: S. M. Nikolaienko, (vidp. red.) ta in.- K. : Milenium Vyp. 259.

7. Voiskunskyi A.E. Psykholohycheskye aspekts deiatelnosty cheloveka v Ynternet-srede [Psychological aspects of human activity in the Internet environment] [Electronic resource]. Rezhym dostupa : psynet.by.ru/texts/voysk $2 . \mathrm{htm}$. 